\title{
Genetic Variability and Character Association in Some Native Orchid Species (Dendrobium spp.)
}

\author{
M. Moniruzzaman ${ }^{1}$, M. A. Zaman ${ }^{2}$, M. Earshad Hossain ${ }^{3}$, M. M. H. Bhuiyan ${ }^{4}$, and M. Z. Rahman ${ }^{5}$ \\ ${ }^{1}$ Floriculture Division, BARI, Gazipur, ${ }^{2}$ PRS, BARI, Gazipur, ${ }^{3}$ Janata Bank, Dhaka, ${ }^{4}$ RARS, BARI, \\ Jessore and ${ }^{5}$ HRC, BARI, Gazipur, Bangladesh \\ *Corresponding author and Email: akzaman118@yahoo.com
}

Received: 23 May $2011 \quad$ Accepted: 26 May 2012

\begin{abstract}
An experiment was carried out using 20 native Dendrobium orchids in Completely Randomized Design (CRD) with three replications at the Orchidarium of Landscape, Ornamental and Floriculture Division, HRC, BARI, Gazipur during the period January 2007 to June 2007 to estimate genetic variability, genetic parameters and correlation coefficient among different flower components. Highly significant variations were observed among the genotypes for all the characters. High broad sense heritability with high genetic advance was observed in spike length (94.00\% and 98.29), rachis length (95.34\% and 93.85), flower durability (94.00\% and 89.00) and floret number $(70.50 \%$ and 65.47$)$ indicating additive gene action, suggesting the possibility of improvement of these traits through selection. Other characters exhibited moderate broad sense heritability with low genetic advance. The number of florets per spike recorded a highly significant association with flower durability, rachis length and spike length. Durability of flower had significant positive correlation with rachis length, flower size and spike length at both genotypic and phenotypic level. Highly significant positive correlation was also found between rachis length and spike length. However, the correlation study revealed that selection of parents should be done based on characters such as floret number, rachis length and flower durability which would be useful in a breeding program. The path analysis revealed that rachis length, durability of flower and number of flowers per spike had contributed maximum direct effects on flower yield, indicating the importance of these three characters as selection criteria for native Dendrobium orchid.
\end{abstract}

\section{Keywords: Genetic variability, heritability, genetic advance, Dendrobium orchid}

\section{Introduction}

There are more than 35000 species of orchids in about 800 genera (Gupta et al., 1997) distributed mostly in tropical and sub-tropical regions of the world covering about seven percent of flowering plants. They belong to the family Orchidaceae and are found in diverse habits and habitats, all over the world except in the dry deserts, snow peaks and cold Polar Regions (Nash, 1997). In Bangladesh, the agro ecological conditions are very conducive for the survival and culture of orchids. As such different species of orchids are widely distributed in the country both in forest and non-forest areas (Chowdhury, 1975). Orchids are commonly found in Sylhet, Rangamati, Cox's Bazar, Rajshahi, Jessore, Sherpur, Madhupur (Tangail), Bandarban, Sundarban, Chittagong and Hilly areas of Bangladesh. They are of immense horticultural importance and play a very useful role to balance forest ecosystem (Mollah, 2001). 
Dendrobium is the most popular orchid in cut flower trade $(>80 \%)$ in Asia for its magnificent flowers of great delicacy, beauty and long vase life. The genus has supplied the second largest number of species in the Orchidaceae family and comprises about 1600 species distributed in Bangladesh, India, Myanmar, Malaysia, Singapore, Indonesia, China and Japan. The cut flowers as well as pot plants of Dendrobium have high demand in the USA, Japan, Italy, Europe and West Germany (Prokash, 1994). Thailand alone exports Dendrobium worth more than U.S \$ 12 million in every year. However, developing countries like Malaysia, Singapore and Sri Lanka are fast catching up the international market and run the Dendrobium cut-flower industry on cooperative basis.

Success of genetic improvement of any crop depends upon the extent of available variability and its subsequent skillful management towards selection of desirable type. Orchid is a high value flowering crop but limited attempt has been made for its genetic improvement. The Floriculture Division of BARI, Gazipur, has a collection of more than 20 species of native Dendrobium possessing wide variabilities in respect of both plant and floral characteristics. Expression of different plant characters is controlled by genetic and environmental factors. It is often difficult to know the proportion of heritable and environmental variation. The progress of breeding is conditioned by the magnitude, nature and interaction of genotypic and environmental variations in the plant characters. So, study of genetic parameters is necessary for a successful breeding program. This will provide valuable information on the mode of inheritance of different characters which would be useful in selecting plants with desirable characters to develop new varieties of orchids in the country. Therefore, the present study was undertaken to obtain information on genetic parameters as well as character associations especially between flowers and other flower contributing characters in Dendrobium orchids.

\section{Materials and Methods}

The experiment was carried out using 20 native Dendrobium orchids in a Completely Randomized Design (CRD) with three replications at the Orchidarium of Landscape, Ornamental and Floriculture Division of HRC, Bangladesh Agricultural Research Institute (BARI), Gazipur during January 2007 to June 2007. One germplasm represented one treatment and each replication included three plants of a germplasm. The orchidarium was facilitated to provide mist irrigation when necessary. Two ponds measuring $28 \times 5 \times 3 \mathrm{~m}$ were established within the orchid house and were kept the pond full of water always to maintain required the humidity in the orchidarium. Major disease incidence and pest infestations were not observed during the study. However, all the plants of 20 native germplasms were given similar cultural treatments throughout the year. Ohio W. P. nutrient solutions were sprayed after 20 days interval. The sources of orchid germplasm are summarized in Table 1.

The genotypic and phenotypic variance was calculated according to Johnson's formula (Johnson et al., 1955). Estimation of genotypic and phenotypic coefficients of variation was calculated according to Burton (1952). Heritability in broad sense was estimated according to Lush (1943). Genetic advance in percent of mean was calculated by following Comstock and Robinson (1952). 
Table 1. Name and source of collection in native Dendrobium orchid germplasms

\begin{tabular}{lll}
\hline SL. No. & Name of germplasm & Source of collection \\
\hline $\mathrm{D}_{1}$ & Dendrobium formosum & Srimongal, Sylhet \\
$\mathrm{D}_{2}$ & D. farmeri & Kaptai, Chittagong \\
$\mathrm{D}_{3}$ & D. bensoni & Kaptai, Chittagong \\
$\mathrm{D}_{4}$ & D. parshii & Kaptai, Chittagong \\
$\mathrm{D}_{5}$ & D. monticola & Tekhnaf, Cox's Bazar \\
$\mathrm{D}_{6}$ & D. lindeyii & Tekhnaf, Cox's Bazar \\
$\mathrm{D}_{7}$ & D. transparens & Srimongal, Sylhet \\
$\mathrm{D}_{8}$ & D. pieardii & Hill Tracts, Burma Border \\
$\mathrm{D}_{9}$ & D. moschatum & Jaintapur, Sylhet \\
$\mathrm{D}_{10}$ & D. terminale & Hill Tracts, Burma Border \\
$\mathrm{D}_{11}$ & D. chrysanthemum & Jaintapur, Sylhet \\
$\mathrm{D}_{12}$ & D. chrysotoxum & Tekhnaf, Cox's Bazar \\
$\mathrm{D}_{13}$ & D. peguanum & Tekhnaf, Cox's Bazar \\
$\mathrm{D}_{14}$ & D. longicornu & Jaintapur, Sylhet \\
$\mathrm{D}_{15}$ & D. fimbriatum & Jaintapur, Sylhet \\
$\mathrm{D}_{16}$ & D. densiflorum & Jaintapur, Sylhet \\
$\mathrm{D}_{17}$ & D. miniature & Jaintapur, Sylhet \\
$\mathrm{D}_{18}$ & D. nobile & Hill Tracts, Burma Border \\
$\mathrm{D}_{19}$ & D. multiflorum & Hill Tracts, Burma Border \\
$\mathrm{D}_{20}$ & D. bellatulum & Hill Tracts, Burma Border \\
\hline & & \\
\hline
\end{tabular}

\section{Results and Discussion}

\subsection{Estimates of genetic parameters in Dendrobium orchids}

The analysis of variance revealed significant differences among the genotypes for all the characters indicating the prevalence of genetic variability. The range, coefficient of phenotypic and genotype variations, heritability estimates and expected genetic advance in percent of mean (1\%) are given in Table 2. A wide range of variation was observed for all the fifteen characters studied and the phenotypic variation was higher than genotypic variation in all the characters indicating that environmental influence. The range of variation was high for spike length (2.0-29), rachis length (1.5-18.0), flower durability (8.0-31.0) and plant height (1371 ) but low for root thickness (0.17-0.70).
Orchid being a cross pollinated crop has much variation and therefore, the present observation is in agreement with that reported earlier by Sultana (2003). In the present study, a narrow difference between phenotypic and genotype coefficients of variation was noticed for spike length, rachis length, plant height, floret number and flower durability, indicating less environmental interference on the expression of these characters. Similar observations were made by Anuradha and Gowdha (1994) in gladiolus. A character can be improved only if it is highly heritable. The magnitude of $\mathrm{h}_{\mathrm{b}}{ }^{2}$ indicates the effectiveness with which the selection of genotypes can be made based on phenotypic performance (Johnson et al., 1955). Out of 15 quantitative characters studied, spike length, rachis length, plant height, floret number and flower durability exhibited high heritability. The results were in agreement with the findings of Singh and Singh (1990) in gladiolus and Sultana (2003) in hybrid orchid. 
Table 2. Phenotypic and genotypic variability, heritability and genetic advance in native Dendrobium orchids

\begin{tabular}{lccccc}
\hline \multicolumn{1}{c}{ Characters } & Range & \multicolumn{2}{c}{$\begin{array}{c}\text { Coefficient of variability } \\
(\%)\end{array}$} & $\begin{array}{c}\text { Heritability } \\
\left(\mathrm{h}_{\mathrm{b}}{ }^{2}\right)\end{array}$ & $\begin{array}{c}\text { Genetic } \\
\text { advance in } \\
\text { percent of } \\
\text { mean (at 1\%) }\end{array}$ \\
\cline { 3 - 3 } & & Phenotypic Genotypic & & \\
Plant height & $13.0-71.0$ & 25.50 & 23.74 & 87.00 & 40.99 \\
Leaf length & $3.4-16.0$ & 23.49 & 17.50 & 50.00 & 30.60 \\
Leaf breadth & $0.9-5.2$ & 22.30 & 16.95 & 45.25 & 31.54 \\
No. of pseudobulb/plant & $5.0-15.0$ & 34.00 & 28.00 & 67.77 & 58.35 \\
Diameter of pseudobulb & $0.5-4.3$ & 30.50 & 27.33 & 65.90 & 51.50 \\
No. of spike/plant & $2.0-5.0$ & 31.44 & 26.58 & 68.63 & 58.27 \\
No. of flowers/spike & $6.0-20.0$ & 33.30 & 28.20 & 72.55 & 64.80 \\
Spike length (cm) & $2.0-29.0$ & 40.45 & 38.00 & 94.00 & 98.29 \\
Rachis length (cm) & $1.5-18.0$ & 36.00 & 35.59 & 95.34 & 93.85 \\
Flower size (cm ${ }^{2}$ ) & $1.3-8.0$ & 30.00 & 25.00 & 64.70 & 54.88 \\
Flower durability (days) & $8.0-31.0$ & 32.55 & 31.34 & 94.00 & 89.00 \\
Pod size & $1.2-4.6$ & 24.00 & 21.58 & 74.00 & 48.51 \\
Root number & $6.0-15.0$ & 25.00 & 22.00 & 54.80 & 38.29 \\
Root length & $8.0-40.0$ & 35.58 & 32.00 & 50.00 & 37.90 \\
Root thickness & $0.17-0.7$ & 20.44 & 15.00 & 48.38 & 35.28 \\
& & & & & \\
\hline
\end{tabular}

Even though the $\mathrm{h}_{\mathrm{b}}{ }^{2}$ values indicate of effectiveness of selection based on the phenotypic performance, it does not necessarily mean a high genetic advance for a particular character. Heritability along with estimates of expected genetic advance should be considered while making selection. In crop improvement only the genetic component of variation is important, since only this can guide the breeders.

If the $\mathrm{h}_{\mathrm{b}}{ }^{2}$ of a character is high ( 0.8 or more), selection for this is very effective. This is because there would be close correspondence between genotype and phenotypic variances due to relatively smaller contribution of environment to the phenotype. However, for character with low $\mathrm{h}_{\mathrm{b}}{ }^{2}$ (less than 0.4), selection may be ineffective or virtually impractical due to masking effect of environment on the genotypic effects. The characters exhibiting high $\mathrm{h}_{\mathrm{b}}{ }^{2}$ with high genetic advance in this study were spike length (94.00\% and 98.29), rachis length (95.34\% and 93.85) and flower durability
(94.00\% and 89.00). This indicates the possibility of tranformance of character to the offspring from the parents which can increase the possibility of improvement of these traits through selections (Burton, 1952). Similar observations were made by Faroque (2003) in orchid. The characters exhibited high $\mathrm{h}_{\mathrm{b}}{ }^{2}$ along with low genetic advance in orchid were plant height $(87.00$ and $40.99 \%)$ and pod size (74.00 and $48.51 \%$ ). The high $\mathrm{h}_{\mathrm{b}}{ }^{2}$ coupled with low GA indicates non-additive gene action, including epitasis and dominance. Similar results were reported by Negi et al. (1982) in gladiolus. Other remaining characters exhibited moderate heritability with low genetic advance.

\subsection{Correlation coefficient}

The genotypic and phenotypic correlation coefficients between different pairs of characters in native Dendrobium orchids are presented in Table 3. Character association analysis among flower and flower producing characters (Table 2) 
revealed that all the genotypic correlation coefficients were higher than the corresponding phenotypic correlation coefficients. This indicates the suppressing effect of the environment, which modified the phenotypic expression of these characters by reducing phenotypic coefficients. Anuradha and Gowda (1994) reported that the genotypic correlations were greater than the phenotypic values in gerbera. It was observed that both at genotypic and phenotypic level, length of leaves had simply positive correlation with flower number, flower size, flower durability and rachis length. On the other hand, this trait had negative association with leaf breadth, number of pseudobulb as well as spike length. Breadth of leaf had negative association with leaf number and number of spike but had positive association with the remaining other characters. Number of leaves had positive significant association with number of pseudobulbs per plant. This indicates that number of pseudobulbs will be increased with the increase of total number of leaves. Number of pseudobulbs had significant but negative correlation with number of spikes per plant $\left(\mathrm{r}=-0.235^{*}\right)$, which indicates that number of spike per plant would be increased with the decrease in number of pseudobulbs. Number of pseudobulbs had also simply positive association with flower number, flower durability, rachis length and flower size at both genotypic and phenotypic level.

Correlation coefficient revealed that number of spikes per plant had negative correlation with number of flowers per spike (Table 3). This indicates that number of flowers will be decreased with the increase in number of spike per plant. On the other hand, this trait had simply positive association with flower size, flower durability, rachis length and spike length. The number of florets per spike recorded a positive highly significant association with flower durability, rachis length and spike length. The character had also shown significant but negative correlation with size of flower at both genotypic and phenotypic levels (Table 3). These results agreed with Faroque (2003) and Sultana (2003) in orchids. Durability of flower had significant positive correlation with rachis length, flower size and spike length at both genotypic and phenotypic level. This indicated that flower durability will be increased with the increase of rachis length, flower size and spike length. Highly significant correlation was found between rachis length and spike length. Singh and Singh (1990) reported that the genotypic and phenotypic association between rachis length and spike length in gladiolus was observed to be positive and highly significant, which was corroborating the present findings. This indicated that flower size will be decreased with the increase of rachis length. Similar observation was also reported by Lal et al. (1985) in gladiolus. However, the correlation study revealed that selection of parents based on floret number, rachis length and flower durability would be useful in a breeding programme.

\subsection{Path coefficient analysis}

Path coefficient analysis (Table 4) revealed that rachis length had the highest positive direct effect on spike length which was followed by durability of flower and number of flowers per spike. This might be due to highly significant positive correlation of spike length with the corresponding characters. These results are in agreement with that of Faroque (2003) in orchids and Tejaswini et al. (1994) in tuberose. Among them rachis length, durability of flower and number of flower per spike had higher positive direct effect than their significant positive correlation with yield indicating that selection based on these characters would be effective. On the other hand, length, breadth and number of leaves had negative direct effect on spike length. Similar result was found by Sultana (2003) and Faroque (2003) in orchids. Flower size had also positive direct effect on spike length but its indirect effect on other characters was mostly negative, which consequently resulted negative correlation with spike length. Number of pseudobulbs had negative direct effects through most of its indirect effects and other characters were positive which finally made insignificant 
Table 3. Genotypic $(\mathrm{G})$ and phenotypic $(\mathrm{P})$ correlations among nine characters in twenty native Dendrobium orchids

\begin{tabular}{|c|c|c|c|c|c|c|c|c|c|c|}
\hline Traits & & $\begin{array}{l}\text { Leaf } \\
\text { length }\end{array}$ & $\begin{array}{c}\text { Leaf } \\
\text { breadth }\end{array}$ & $\begin{array}{c}\text { Leaf } \\
\text { number }\end{array}$ & $\begin{array}{c}\text { No. of } \\
\text { pseudobulb } \\
\text { per plant }\end{array}$ & $\begin{array}{l}\text { No. of } \\
\text { spike per } \\
\text { plant }\end{array}$ & $\begin{array}{c}\text { No. of } \\
\text { flowers } \\
\text { per spike }\end{array}$ & $\begin{array}{l}\text { Durability } \\
\text { of flower }\end{array}$ & Rachis length & $\begin{array}{c}\text { Flower } \\
\text { size }\end{array}$ \\
\hline \multirow[t]{2}{*}{ Leaf length } & $\mathrm{G}$ & -0.143 & 0.188 & -0.169 & 0.099 & 0.146 & 0.153 & 0.162 & 0.188 & -0.186 \\
\hline & $\mathrm{P}$ & -0.102 & 0.115 & -0.135 & 0.048 & 0.109 & 0.139 & 0.133 & 0.178 & -0.174 \\
\hline \multirow[t]{2}{*}{ Leaf breadth } & $\mathrm{G}$ & & -0.166 & 0.194 & -0.187 & 0.166 & 0.194 & 0.175 & 0.180 & 0.193 \\
\hline & $\mathrm{P}$ & & -0.108 & 0.147 & -0.175 & 0.155 & 0.180 & 0.148 & 0.146 & 0.179 \\
\hline \multirow[t]{2}{*}{ Leaf number } & $\mathrm{G}$ & & & $0.234 *$ & 0.181 & $0.234^{*}$ & 0.128 & 0.174 & -0.175 & 0.165 \\
\hline & $\mathrm{P}$ & & & $0.219^{*}$ & 0.174 & $0.215^{*}$ & 0.105 & 0.115 & -0.105 & 0.152 \\
\hline \multirow[t]{2}{*}{ No. of pseudobulbs per plant } & $\mathrm{G}$ & & & & $-0.235^{*}$ & 0.188 & 0.190 & 0.189 & 0.171 & 0.181 \\
\hline & $\mathrm{P}$ & & & & $-0.198 *$ & 0.109 & 0.186 & 0.155 & 0.164 & 0.157 \\
\hline \multirow[t]{2}{*}{ No. of spikes per plant } & $\mathrm{G}$ & & & & & -0.174 & 0.130 & 0.165 & 0.154 & 0.175 \\
\hline & $\mathrm{P}$ & & & & & -0.106 & 0.114 & 0.101 & 0.098 & 0.127 \\
\hline \multirow[t]{2}{*}{ No. of flowers per spike } & $\mathrm{G}$ & & & & & & $0.408 * *$ & $0.456 * *$ & $-0.256^{*}$ & $0.291 *$ \\
\hline & $\mathrm{P}$ & & & & & & $0.334 * *$ & $0.364 * *$ & $-0.219^{*}$ & $0.199 *$ \\
\hline \multirow[t]{2}{*}{ Durability of flower } & $\mathrm{G}$ & & & & & & & $0.393 * *$ & $0.218^{*}$ & $0.420 * *$ \\
\hline & $\mathrm{P}$ & & & & & & & $0.248 * *$ & $0.203^{*}$ & $0.315^{* *}$ \\
\hline \multirow[t]{2}{*}{ Rachis length } & $\mathrm{G}$ & & & & & & & & -0.189 & $0.454 * *$ \\
\hline & $\mathrm{P}$ & & & & & & & & -0.106 & $0.338^{* *}$ \\
\hline \multirow[t]{2}{*}{ Flower size } & $\mathrm{G}$ & & & & & & & & & -0.149 \\
\hline & $\mathrm{P}$ & & & & & & & & & -0.116 \\
\hline
\end{tabular}

* Indicate $5 \%$ level of significant (using mean values)

** Indicate $1 \%$ level of significant (using mean values), Significant values of $\mathrm{r}(5 \%=0.198,1 \%=0.244)$ 
Table 4. Path coefficient of flower producing character on length of spike in native Dendrobium orchid germplasm

\begin{tabular}{|c|c|c|c|c|c|c|c|c|c|c|}
\hline Traits & $\begin{array}{c}\text { Leaf } \\
\text { length }\end{array}$ & $\begin{array}{c}\text { Leaf } \\
\text { breadth }\end{array}$ & $\begin{array}{c}\text { Number } \\
\text { of } \\
\text { leaves }\end{array}$ & $\begin{array}{l}\text { Number of } \\
\text { pseudobulbs } \\
\text { /plant }\end{array}$ & $\begin{array}{l}\text { Number of } \\
\text { spike/plant }\end{array}$ & $\begin{array}{l}\text { Number of } \\
\text { flowers/ } \\
\text { spike }\end{array}$ & $\begin{array}{c}\text { Flowering } \\
\text { duration }\end{array}$ & $\begin{array}{l}\text { Rachis } \\
\text { length }\end{array}$ & $\begin{array}{c}\text { Flower } \\
\text { size }\end{array}$ & $\begin{array}{l}\text { Genetic } \\
\text { correlation with } \\
\text { spike length }\end{array}$ \\
\hline Leaf length & $\underline{-0.141}$ & 0.028 & -0.001 & 0.044 & -0.085 & 0.154 & 0.145 & 0.138 & 0.027 & -0.186 \\
\hline Leaf breadth & 0.312 & $\underline{-0.045}$ & 0.021 & -0.125 & -0.003 & 0.144 & 0.051 & 0.145 & 0.110 & -0.193 \\
\hline $\begin{array}{l}\text { Number of } \\
\text { leaves }\end{array}$ & -0.078 & 0.098 & $\underline{-0.050}$ & -0.135 & 0.143 & 0.187 & 0.164 & 0.143 & -0.165 & 0.165 \\
\hline $\begin{array}{l}\text { Number of } \\
\text { pseudobulbs }\end{array}$ & 0.084 & 0.014 & 0.135 & $\underline{-0.162}$ & 0.121 & 0.196 & 0.164 & 0.235 & 0.128 & 0.188 \\
\hline $\begin{array}{l}\text { Number of } \\
\text { spikes per } \\
\text { plant }\end{array}$ & -0.040 & 0.024 & -0.011 & -0.023 & $\underline{0.017}$ & 0.033 & 0.120 & 0.132 & -0.015 & 0.175 \\
\hline $\begin{array}{l}\text { Number of } \\
\text { flowers per } \\
\text { spike }\end{array}$ & 0.050 & 0.048 & 0.020 & 0.034 & 0.027 & $\underline{0.304}$ & 0.015 & 0.091 & -0.090 & 0.291 \\
\hline $\begin{array}{l}\text { Flowering } \\
\text { duration }\end{array}$ & 0.450 & 0.029 & -0.041 & -0.056 & 0.042 & 0.031 & $\underline{0.445}$ & 0.113 & 0.003 & 0.420 \\
\hline Rachis length & 0.282 & 0.015 & -0.013 & 0.092 & 0.055 & 0.139 & 0.159 & $\underline{0.516}$ & -0.024 & 0.454 \\
\hline Flower size & -0.052 & -0.027 & 0.057 & -0.135 & 0.013 & -0.115 & -0.019 & 0.096 & $\underline{0.133}$ & -0.149 \\
\hline
\end{tabular}

Residual effect: 0.30

Underline figures indicate the direct effect 
negative correlation between pseudobulb and spike length. The results are in agreement with that of Faroque (2003) in orchids.

The residual effect towards yield found in this study was 0.30 indicating that 70 percent of the variability in spike length was contributed by the ten characters studied in the path analysis. This residual effect towards yield in the present study might be due to other characters which were not studied, environmental factors and sampling errors (Sharifuzzaman, 1998). The path analysis indicated that rachis length, durability of flower and number of flowers per spike had contributed maximum direct effects on flower yield indicating the importance of these three characters as selection indices for native Dendrobium orchid.

In the present study, the range of variation was high for spike length, rachis length, flower durability and plant height but low for root thickness. A narrow difference between phenotypic and genotype coefficients of variation was noticed for spike length, rachis length, plant height, floret number and flower durability, indicating less environmental interference on the expression of these characters. Broad sense heritability along with estimates of expected genetic advance is an important tool to find out the effectiveness of selection. The characters exhibiting high $\mathrm{h}_{\mathrm{b}}{ }^{2}$ with high genetic advance in this study were spike length, rachis length and flower durability. This indicates additive gene action, suggesting the possibility of improvement of these traits through selection. From the correlations study, it is revealed that selection of parents based on characters such as floret number, rachis length and flower durability would be useful in a breeding programme. The path analysis also indicated that rachis length, durability of flower and number of flowers per spike had contributed maximum direct effects on flower yield indicating the importance of these three characters as selection indices for native Dendrobium orchid.

\section{Conclusions}

Genetic variability was analyzed to determine the more the more variable characters which might be used in the breeding programme. This study has shown that genotypes should be selected on the basis of spike length, rachis length, flower durability and plant height, because these are the more variable characters among the genotypes. Correlation and path coefficient analysis revealed that floret numbers, rachis length, flower durability and number of flowers per spike had maximum direct effect on flower size indicating the importance of these characters as selection criteria for the development of Native Dendrobium orchids.

\section{References}

Anuradha, S. and Gowdha, J. V. 1994. Correlation studies in Gladiolus. In: Floriculture -Technology, Trades and Trends. (eds.) J. Prakash and K. R. Bhandry, Oxford and IBH Publishing Co. Pvt. Ltd. Calcutta, 285-287 pp.

Burton, G. W. 1952. Quantitative inheritance in grasses. Proc. $6^{\text {th }}$ International Grassland Congress, $277-283$ pp.

Chowdhury, M. 1975. Orchid cultivation (a leaflet). Baldah Garden, Dhaka, Bangladesh, 12-15 pp.

Comstock, R. E. and Robinson, H. F. 1952. Genetic Parameter, their estimation and significance. Proc. $6^{\text {th }}$ International Grassland Congress, 1: 284-291.

Faroque, A. A. 2003. Study on the variabilities, correlation and morphological characteristics of different local orchids. An M.S. Thesis submitted to the Department of Horticulture, BAU, Mymensingh, Bangladesh, 4-90 pp.

Gupta, P. D., Forkan, M. A. and Bhadra, S. K. 1997. Micropropagation through seeds and 
shoot segments in Dendrobium crepidatul. Plant Tissue Culture, 8 (1): 1-10.

Johnson, H. W., Rabinson, H. F. and Comstock. R. E. 1955. Estimation of genetic and environmental variability in soyabeans. Agronomy Journal, 47: 314-318.

Lal, S. D., Shah, A. and Seth, J. N. 1985. Genetic variability in gladiolus. Progressive Horticulture, 17(1): 31-34.

Lush, J. L. 1943. Animal Breeding Plans. Iowa State Press, Ames, Iowa, 437 p.

Mollah, S. 2001. Orchid (a leaflet). Floriculture Division, HRC, BARI, 1-30 pp.

Nash, N. 1997. Use of Cocohusk in Orchids. Orchids. 66: $1268-1277$.

Negi, S. S. Sharma, T. V. R. S., Raghava, S. P. S. and Srinivasan, V. R. 1982. Variability studies in gladiolus. Indian Journal of Horticulture, 39: 269 -272.

Prokash, D. 1994. Standardization of different containers, potting media and nutrient solution for dendrobium hybrids. Souvenir and Abstracts. National seminar on a decade of orchid research and development. The Orchid Society of India, 90-91 pp.

Sharifuzzaman, S.M. 1998. Physio morphological characteristics and yield potentials of bush bean genotypes. An M.S. Thesis submitted to the Department of Horticulture. IPSA, Salna, Gazipur, Bangladesh, 45-65 pp.

Singh, B. and Singh, M. 1990. Studies on variability and genetic advance parameters in gladiolus. Progressive Horticulture, 19 (3-4): 271-275.

Sultana, K. S. 2003. Study on variabilities and morphological characteristics of some hybrid orchids. An M.S. Thesis submitted to the Department of Horticulture, BAU, Mymensingh, Bangladesh, 10-80 pp.

Tejaswini, Murthy, N. and Bhat, R. N. 1994. Potential and possibilities in tuberose breeding. In: Florculture-Technology, Trades and Trends. (eds.) J. Prakash and K. R. Bhandry. Oxford and IBH Publishing Co. Pvt. Ltd. Calcutta, 313-317 pp. 